\title{
Airway symptoms and lung function in the local population after the oil tank explosion in Gulen, Norway
}

\author{
Jens-Tore Granslo ${ }^{1,2^{*}}$, Magne Bråtveit ${ }^{2}$, Bjørg Eli Hollund ${ }^{1}$, Ågot Irgens ${ }^{1}$, Cecilie Svanes ${ }^{1,3}$, Nils Magerøy ${ }^{1}$
} and Bente Elisabeth Moen ${ }^{1,2}$

\begin{abstract}
Background: Oil tanks containing a mixture of hydrocarbons, including sulphuric compounds, exploded and caught fire in an industrial harbour. This study assesses airway symptoms and lung function in the nearby population $1 \frac{1}{2}$ years after the explosion.
\end{abstract}

Methods: A cross-sectional study included individuals $\geq 18$ years old. Individuals living $<6 \mathrm{~km}$ (sub-groups $<3 \mathrm{~km}$ and 3-6 km) from the accident site formed the exposed group, individuals living $>20 \mathrm{~km}$ away formed a control group. A questionnaire and spirometry tests were completed by 223 exposed individuals (response rate men 70\%, women 75\%) and 179 control individuals (response rate men 51\%, women 65\%). Regression analyses included adjustment for smoking, occupational exposure, atopy, infection in the preceding month and age. Analyses of symptoms were also adjusted for stress reactions related to the accident.

Results: Exposed individuals experienced significantly more blocked nose (odds ratio 1.7 [95\% confidence interval $1.0,2.8])$, rhinorrhoea $(1.6[1.1,3.3])$, nose irritation $(3.4[2.0,5.9])$, sore throat $(3.1[1.8,5.5])$, morning cough $(3.5[2.0$, $5.5])$, daily cough $(2.2[1.4,3.7])$, cough $>3$ months a year $(2.9[1.5,5.3])$ and cough with phlegm $(1.9[1.2,3.1])$ than control individuals. A significantly increasing trend was found for nose symptoms and cough, depending on the proximity of home address to explosion site (daily cough, $3-6 \mathrm{~km} 1.8[1.0,3.1],<3 \mathrm{~km} 3.0$ [1.7, 6.4]). Lung function measurements were significantly lower in the exposed group than in the control group, $\mathrm{FEV}_{1}$ adjusted mean difference $-123 \mathrm{~mL}$ [95\% confidence interval $-232,-14]$ ), FEV $1 \%$ predicted $-2.5[-5.5,0.5]$, FVC $-173 \mathrm{~mL}[-297,-50]$, FVC\% predicted $-3.1[-5.9,-0.4]$, and airway obstruction (GOLD I/III).

Conclusions: Based on cross sectional analyses, individuals living in an area with air pollution from an oil tank explosion had more airway symptoms and lower lung function than a control group $1 \frac{1}{2}$ years after the incident.

Keywords: Airway symptoms, Environmental pollutants, Explosion, Lung function

\section{Background}

One morning in May 2007, an oil tank exploded, caught fire and ignited a nearby tank with similar contents. Sooty smoke spread in a north-easterly direction until the fire was extinguished in the afternoon. The oil tanks were located in a one-square-kilometre industrial

\footnotetext{
* Correspondence: jens-tore.granslo@helse-bergen.no

'Department of Occupational Medicine, Haukeland University Hospital, Bergen, Norway

${ }^{2}$ Department of Public Health and Primary Health Care, University of Bergen, Bergen, Norway

Full list of author information is available at the end of the article
}

harbour area by a fiord in Gulen municipality, Western Norway. The industrial harbour is located in a rural area. Except for the industrial harbour there are no industrial emission sites and the nearest town is more than 50 kilometres air distance to the south.

No one died or was seriously injured, but for many months the local population reported an unpleasant smell from the area. In a report to the authorities, local physicians described various health symptoms in the population, such as sore throats and headaches [1]. The event was discussed in the mass media for a long time. Health concerns called for an initiative and, in 2008, the

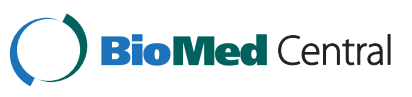


national health authorities decided to carry out a health examination of the local population.

Few studies have examined persistent respiratory effects after chemical disasters or other air-polluting accidents. Three months after the catastrophe at the World Trade Center (WTC) in 2001, 191 federal office employees (response rate 68\%) who worked in three federal buildings near the WTC and a control group of 155 (response rate 47\%) federal office employees in Dallas, Texas, participated in a cross-sectional questionnaire based survey. The prevalence of upper and lower airway symptoms and also of mental health symptoms was higher among the NY employees [2]. About one year (8-16 months) after the WTC accident a selfadministrated questionnaire based study was conducted on 2520 residents from households in buildings within a radius of 1 mile $/ 1.5 \mathrm{~km}$ from the accident site (household response 22.3\%) and a control group of 292 residents (household response 23.3\%) in buildings in Upper Manhattan, NY, more than 4.8 miles $/ 9 \mathrm{~km}$ north of the accident site $[3,4]$. Participants who lived near the WTC had more upper and lower airway symptoms than the control subjects $[3,4]$, but lung function was not significantly different $(p>0.05)$ [3]. Six years after a fire in a chemical waste depot containing batteries, acids, bases and paint and 480 metric tons of chemical waste was burnt in the town Drachten in the Netherlands, 138 subjects who had been present in the area at the time of the fire were telephone interviewed for lower respiratory symptoms as part of a case-control study [5]. The interviewed subjects with reported normal respiratory health before the accident were selected for pulmonary examination. All participants with new lower airway symptoms for more than three months after the fire were selected as cases $(n=25)$, a randomly selected group without these criteria $(n=99)$ was control. Cases were more likely to have been working or staying within 100 metres of the fire site (high exposed) than more than one kilometre away (low exposed) compared with control subjects. The cases had significantly lower forced expiratory volume one second per cent predicted $\left(\mathrm{FEV}_{1} \%\right.$ predicted) and higher dose-response slope (DRS) with bronchial histamine provocation than control subjects. High exposed subjects had borderline significantly lower $\mathrm{FEV}_{1} \%$ predicted $(\mathrm{p}=0.099)$ and borderline higher DRS with histamine provocation $(\mathrm{p}=0.056)$ than low exposed subjects [5]. One to two years after the clean-up of the oil spill from the tanker Prestige off the coast of Spain, a questionnaire based cross-sectional study of 6869 costal fishermen (response rate 76\%) from 38 cooperatives along the cost was performed. Local fishermen on the most polluted coastline who took part in clean-up activities had more airway symptoms than a control group of fishermen from non-polluted areas [6]. About two years after the accident a group of the most exposed fishermen $(n=501)$ and a group of fishermen from the low exposed costal line who did not take part in clean-up activities $(n=177)$ were examined for health effects from the exposure including lung function measurements [7]. This study confirmed the results from the questionnaire based study that exposed had significantly more airway symptoms than control subjects, but nasal symptoms and lung function was not significantly different between the exposure groups, neither was the nonspecific bronchial reactivity measured with metacholine provocation [7].

These studies varied with respect to exposure, effect measures, time delayed between exposure and study and in study design. The population in the present study is relatively stable and homogenous, and together with the relatively low ambient air pollution expected to be present under normal circumstances in this area, this study could provide interesting information on the effect of an air polluting accident.

Another aspect of this kind of accident is the effect of prolonged media coverage on symptoms in the population. Individuals who have read and heard about disasters through the mass media may develop post- traumatic stress-related symptoms $[8,9]$, and medically unexplained physical symptoms [9]. Adjusting for stress symptoms might lead to better estimates of event-related risk of selfreported symptoms in an affected population. However, possible persistent airway symptoms caused by air pollution from the accident may also contribute to longer lasting stress reaction related to the incident.

The main aim of this study was to assess the prevalence of airway symptoms and lung function in an adult population living close to an air-polluting explosion site compared with a population living far away.

\section{Methods}

\section{Exposure}

The tank that exploded contained remnants of sulphuric gasoline (coker gasoline), $50 \mathrm{~m}^{3}$ of alkalinised sludge containing sodium thiolates (mercaptans), $200 \mathrm{~m}^{3}$ of treated wastewater and $15 \mathrm{~m}^{3}$ of concentrated hydrochloric acid. The smoke content was not analysed, but thiols and other sulphides were probably oxidised, forming sulphuric dioxide $\left(\mathrm{SO}_{2}\right)$ during the fire. Air measurements in the industrial harbour two to three weeks after the accident showed low levels of mercaptans [10]. Sulphuric compounds from the tanks were probably also spread to the soil and water in the industrial area.

Clean-up operations started soon after the accident. Contaminated soil was collected and stored in big bags, but was not removed from the harbour area until 2010, three years later. 
In an area west, north and east of the accident site within a distance of six kilometres there are individual and small clusters of houses spread within the whole area mainly along the roads. This area is separated by fields, hills and woodland from houses further away. South and south west of the harbour is the fiord. Except for their neighbourhood to the industrial harbour the inhabitants in this area, which belong to two municipalities, live in a rural environment with low road traffic. The average distance from the accident site to the residential addresses for the inhabitants is about 3.7 kilometres (range 1-6 km).We anticipated that the highest environmental chemical exposure from the accident had been within this area, and all the inhabitants here were defined as exposed to the pollution from the accident. We also anticipated that people living 1-3 kilometres from the accident site had been more exposed to pollution from the accident than those living 3-6 kilometres away. The control group was selected from inhabitants living in two separate areas to the east and north east of the industrial harbour in the same two municipalities as the exposure area, but an average 28 kilometres away (range $>20-30 \mathrm{~km}$ ). We anticipated low accident related exposure in the control areas, but otherwise the residence environment was considered to be similar to the area where the exposed population lived, with small clusters of houses in a rural environment.

\section{Study design and population}

This cross sectional study was carried out 18 months after the explosion, from November 2008 to March 2009. Information about residence was obtained from the National Population Register.

All inhabitants from 18 years old and upwards living within six kilometres (average distance 3.7 kilometres) of the accident site at the time of the incident were defined as exposed $(\mathrm{N}=308)$. A random sample of inhabitants living more than 20 kilometres away (average distance 28 kilometres) in the same two municipalities, were defined as controls $(\mathrm{N}=316)$. These controls had the same age and gender distributions as the exposed.

The population was informed about the study at a public meeting, through the local press, television channels and posters in public buildings. A letter inviting recipients to a health examination in the local municipality, a questionnaire and up to two reminders were sent by mail to each selected person.

Lists of workers employed in the industrial harbour at the time of the accident were obtained from the local employers. Inhabitants in the control group who worked in the industrial harbour were excluded from the study population.

A total of 402 individuals participated, 223 in the exposed group (115 men, response rate $70 \%$, and 108 women, response rate $75 \%$ ), and 179 in the control group (99 men, response rate $51 \%$ and 80 women, response rate $65 \%$ ). In the exposed group, 59 men and 55 women lived within three kilometres, and 56 men and 53 women lived from three to six kilometres from the explosion site. The non-responder group comprised mostly of younger adults, especially younger men.

\section{Airway symptoms}

Questions about symptoms from lower airways included (yes/no): Usually morning cough, daily cough, cough at least three months a year, cough with phlegm, cough with phlegm at least three months a year, dyspnoea while walking on flat ground, dyspnoea while walking uphill compared to others, ever had episodes of wheezing from chest, were taken from the ATS-DLD-78A questionnaire [11].

Questions about current symptoms from upper airways: Blocked nose, rhinorrhoea, irritated nose and sore throat, were taken from the Wasserfallen et al. validated questionnaire [12]. Participants were to report the degree of present symptoms on a five-point scale (0-4).

\section{Lung function}

Spirometry was performed in accordance with the ATS/ ERS standardisation recommendation from 2005 [13], but accepting $200 \mathrm{~mL}$ repeatability in accordance with the 1994 recommendation [14]. A dry wedge spirometer, 'Vitalograph Gold Standard plus' (model 2160) was used for all measurements. Among men, 99 spirograms were found to be acceptable in the exposed group and 91 in the control group; for women, the figures were 94 and 71 , respectively.

The chosen forced expiratory volume in one second $\left(\mathrm{FEV}_{1}\right)$ and forced vital capacity (FVC) were compared with reference (predicted) values from a non-smoking, healthy, west-coast Norwegian population [15]. Spirometry was performed before and 15 minutes after inhaling $0.4 \mathrm{mg}$ adrenergic beta2-agonist salbutamol from a Discus inhalator [16]. Airway obstruction was defined as $\mathrm{FEV}_{1} \%$ predicted $<80 \%$ and an $\mathrm{FEV}_{1} / \mathrm{FVC}$ ratio $<0.70$, which is moderate and severe obstruction according to the GOLD criteria [17].

\section{Post-traumatic stress symptoms}

To assess stress symptoms relating to the 2007 accident, questions were included from the Impact of Event ScaleRevised (IES-R) [18]. This scale is suggested to be useful when screening for signs of post-traumatic stress (PTSD) [19]. It contains 22 questions on different stress symptoms experienced during the past week relating to the 2007 accident. Answers were given on a five-point scale, from 0 (not at all) to 4 (extreme). The maximum 
obtainable impact score was 88 , a high number representing a high symptom level. A cut-off value of 22 was used as this has been shown to be optimal for classification accuracy, sensitivity and specificity of PTSD [20].

\section{Population characteristics and covariates}

The participants were asked (yes /no): Have you had an infection in the preceding month, and have you cat or dog, moisture damage or carpeted floors in your home. They were also asked about years of education after lower secondary school, whether they were working, were on sick leave or rehabilitation, in receipt of disability pension, retirement pension or were students.

Subjects in employment were asked to state their occupation and industry using free text. Information about current occupation was coded as a three-digit code in accordance with the Norwegian version of the International Standard Classification of Occupation (ISCO -88) by two skilled researchers [21]. The individual's occupation was then linked to a general population jobexposure matrix (JEM) which classifies each occupation into none, low or high exposure according to occupational exposure to mineral dust, biological dust or fumes/gases [22]. In the present study we classified these three exposure groups into two where the original none and low exposure groups were merged.

Information was also obtained about years of daily smoking, previous smoking (yes/no), and cigarettes per day for current smokers. Smoking was defined as present versus never/previous smoking.

A blood sample was taken by vein puncture, and the blood was coagulated in tubes at room temperature and centrifuged for serum within two hours. Serum was analysed at the laboratory at Haukeland University Hospital the next day using Phadiatop ${ }^{\circledR}$ based on the ImmunoCAP-FEIA system (Phadia AB, Uppsala, Sweden). Subjects with positive Phadiatop ${ }^{\circledR}$ (specific IgE toward one or more of the following airway allergens: Dermatophagoides pteronyssinus, Cladosporium herbarum, cat, dog, horse, birch, timothy and mugwort) results were defined as having atopy.

The height and weight of participants were measured while wearing indoor clothing without shoes and jacket. Height was used as a covariate.

The described population characteristics and covariates were assessed because they may be associated with respiratory health or lung function.

\section{Statistical analyses}

Comparison of characteristics variables among exposed and controls were done by Pearson Chi-Square test, or Fisher exact test for small numbers in categorical variables. Continuous variables were compared by independent sample t-tests. However, when the continuous variables were not normally distributed, the Mann-Whitney $U$ test was used.

The relationship between categorical airway symptoms and exposure groups was analysed by logistic regression, adjusting for smoking (present versus previous or never), present occupational exposure (high versus low), Phadiatop ${ }^{\circledR}$ (positive versus negative), infection in the preceding month (yes versus no), age (continuous scale) and impact score $(\geq 22$ versus $<22)$. The answers to the upper airway symptoms were dichotomised; answers 0 and 1 were defined as no symptom and 2 to 4 as symptom present. We categorized the answers to these questions, as the underlying variables are naturally categorical (like symptoms from lower airways) [23]. Regression analyses with adjustments were not performed if the number were less than six individuals in any of the exposure groups. The relationship between continuous values as spirometry results and exposure was analysed by linear regression models, adjusting for smoking, occupational exposure, Phadiatop ${ }^{\circledR}$, infection in the preceding month, age and height.

Most comparisons were performed for both genders and for men and women separately. When analysing men and women together, adjustment for gender (women versus men) was done.

In order to investigate a possible exposure-response of air polluting airway effect on the population within the 6 kilometre distance from the site, we made post-hoc calculations by analysing the airway effects separately for those living within three kilometres and those living 3-6 kilometres of the site, both compared to the control group. In total, 59 men and 55 women lived within three kilometres (average distance 26 kilometres), and 56 men and 53 women lived from three to six kilometres from the explosion site (average distance 4.7 kilometres).

If there were missing data points such as if a participant did not fill in a question in the questionnaire, this question was not used for that person in analyses. An exception for omitting a missed data point was if it seemed logical not doing so out of the context for the question. If a person answered "no" to each of the questions "have you usually morning cough", "daily cough" or cough with phlegm", and did not answer the question "have you cough more than three months a year", then we anticipated that the answer also should be "no" here, and we used the answer "no" in the analyse for that question.

The comparative tests were two-sided, and p-values below 0.05 were considered significant. SPSS 18.0 was used for statistical analyses.

The study was approved by the Regional Committee for Medical Ethics of Western Norway and Norwegian Social Science Data Services. 


\section{Results}

Most population characteristics were similar when the exposed group and control group were compared, including the possible non-occupational environmental risk factors for airway symptoms as cats and dogs at home, building moisture at home and floor carpets at home. The prevalence of atopy among men was significantly lower and present smoking among women significantly higher in the exposed group (Table 1). All respondents with an impact score $\geq 22$ were in the exposed group except for one woman in the control group.

Most airway symptoms were significantly more common in the group living less than six kilometres from the accident site than among control subjects (Table 2). The differences were also statistically significant for nose irritation, sore throat and cough in both men and women, adjusting for potential confounders (Table 3).

Those in the exposed group living less than three kilometres from the accident site had higher odds ratios for most symptoms compared to those living three to six kilometres away. This trend was significant for blocked nose, rhinorrhoea, nose irritations and cough among men (Table 3), and in addition for sore throat when both genders were analysed together (Table 2). The exposureresponse pattern appeared to be less consistent among women than among men (Table 3).

The significant odds ratios in Tables 2 and 3 were still significant after sensitivity testing by excluding participants with impact score above 21 (data not given). In the exposed group living within six kilometres of the accident site, 42 individuals (32 men and 10 women) worked in companies at the site of the accident in May 2007. Adding an adjustment for work in these companies to the regression model did not change the results in Tables 2 and 3 (data not given).

Analysing the relationship between daily coughing and exposure group (home address) yielded a significant relationship between the symptom and residence less than three kilometres from the accident site (Table 4).

Table 1 Characteristics in men and women aged $\geq 18$ years old according to exposure from oil tank explosion

\begin{tabular}{|c|c|c|c|c|c|c|c|}
\hline & & \multicolumn{3}{|c|}{ Men } & \multicolumn{3}{|c|}{ Women } \\
\hline & & $\begin{array}{c}\text { Control } \\
n=99\end{array}$ & $\begin{array}{c}\text { Exposed } \\
n=115\end{array}$ & P- value & $\begin{array}{c}\text { Control } \\
n=80\end{array}$ & $\begin{array}{c}\text { Exposed } \\
n=108\end{array}$ & P-value \\
\hline Age & $\mathrm{AM}(\mathrm{SD})^{\mathrm{a}}$ & $48.3(14.3)$ & $48.2(17.5)$ & $0.95^{b}$ & $47.2(14.9)$ & $45.3(15.9)$ & $0.42^{b}$ \\
\hline At work & n (\%) & $81(82)$ & $84(73)$ & $0.13^{c}$ & $61(76)$ & $77(71)$ & $0.45^{c}$ \\
\hline Sick leave/rehabilitation & n (\%) & $0(0)$ & $3(3)$ & - & $7(9)$ & $8(7)$ & $0.74^{c}$ \\
\hline Disability pension & n (\%) & $5(5)$ & $8(7)$ & $0.78^{c}$ & $6(8)$ & $6(6)$ & $0.76^{c}$ \\
\hline Retirement pension & n (\%) & $9(9)$ & $18(16)$ & $0.15^{c}$ & $7(9)$ & $13(12)$ & $0.47^{c}$ \\
\hline Student & n (\%) & $5(5)$ & $3(3)$ & $0.48^{c}$ & $7(9)$ & $11(10)$ & $0.74^{c}$ \\
\hline Others & n (\%) & $0(0)$ & $0(0)$ & - & $0(0)$ & $2(2)$ & - \\
\hline Years of education after lower secondary school & Med $(\mathrm{Q} 1, \mathrm{Q} 3)^{\mathrm{d}}$ & $3(1,4.5)$ & $3(1,4)$ & $0.34^{f}$ & $3(2,6)$ & $3(2,5)$ & $0.45^{f}$ \\
\hline High occupational exposure & n (\%) & $37(38)$ & $37(32)$ & $0.39^{c}$ & $4(5)$ & $11(10)$ & $0.20^{c}$ \\
\hline \multicolumn{8}{|l|}{ Smoking status } \\
\hline Present smoking & n (\%) & $25(25)$ & $34(30)$ & $0.54^{c}$ & $11(14)$ & $28(26)$ & $0.047^{c}$ \\
\hline Years & Med $(\mathrm{Q} 1, \mathrm{Q} 3)^{\mathrm{d}}$ & $22(14,30)$ & $20(10,37)$ & $0.98^{f}$ & $20(20,35)$ & $22(10,30)$ & $0.99^{f}$ \\
\hline Present cigarettes pr day & Med $(\mathrm{Q} 1, \mathrm{Q} 3)^{\mathrm{d}}$ & $10(9)$ & $12(5)$ & $0.37^{f}$ & $10(9)$ & $10(5)$ & $0.82^{f}$ \\
\hline Earlier smoked & $n(\%)$ & $39(39)$ & $40(35)$ & $0.74^{\mathrm{c}}$ & $30(38)$ & $31(35)$ & $0.56^{c}$ \\
\hline Years & Med $(\mathrm{Q} 1, \mathrm{Q} 3)^{\mathrm{d}}$ & $15(10,22)$ & $18(10,30)$ & $0.62^{f}$ & $15(5,20)$ & $10(8,18)$ & $0.71^{f}$ \\
\hline Never smoked & n (\%) & $33(33)$ & $41(36)$ & $0,84^{c}$ & $37(46)$ & $48(44)$ & $0,28^{c}$ \\
\hline Cats or dogs at home & n (\%) & 39 (39) & $46(40)$ & $0.62^{c}$ & $34(43)$ & $50(46)$ & $0.61^{c}$ \\
\hline Building moisture at home & n (\%) & $8(8)$ & $8(7)$ & $0.90^{c}$ & $4(5)$ & $9(8)$ & $0.79^{c}$ \\
\hline Floor carpets at home & n (\%) & $3(3)$ & $2(2)$ & $0,66^{\mathrm{e}}$ & $4(5)$ & $2(2)$ & $0.40^{\mathrm{e}}$ \\
\hline Infection in the preceding month & n (\%) & $36(37)$ & $33(29)$ & $0.23^{c}$ & $25(31)$ & $39(36)$ & $0.46^{c}$ \\
\hline Impact score $>=22$ & n (\%) & $0(0)$ & $11(10)$ & - & 1(1) & $10(9)$ & $0.026^{\mathrm{e}}$ \\
\hline Height (m) & $\mathrm{AM}(\mathrm{SD})^{\mathrm{a}}$ & $1,79(0,06)$ & $1,79(0,05)$ & $0.71^{\mathrm{b}}$ & $1,67(0,05)$ & $1,66(0,06)$ & $0.32^{b}$ \\
\hline Body mass index $\left(\mathrm{kg} / \mathrm{m}^{2}\right)$ & $\mathrm{AM}(\mathrm{SD})^{\mathrm{a}}$ & $26.5(3.7)$ & $26.9(4.0)$ & $0.52^{\mathrm{b}}$ & $27.6(5.5)$ & $26.3(6.4)$ & $0.14^{\mathrm{b}}$ \\
\hline Phadiatop ${ }^{\circledR}$ positive & n (\%) & $31(31)$ & $22(19)$ & $0.046^{c}$ & $15(19)$ & $25(23)$ & $0.45^{c}$ \\
\hline
\end{tabular}

Exposed status was defined as living $<6 \mathrm{~km}$ (average $3.7 \mathrm{~km}$ ) from the explosion site; control status as living $>20 \mathrm{~km}$ (average $28 \mathrm{~km}$ ) from the explosion site

${ }^{a}$ Arithmetic mean (Standard deviation). ${ }^{b}$ Independent sample t-test. ${ }^{c}$ Pearson Chi-Square test. ${ }^{d}$ Med: Median. Q1: $25^{\text {th }}$ percentile. Q3: $75^{\text {th }}$ percentile

e Fisher exact test. ${ }^{\mathrm{f}}$ Mann-Whitney $\mathrm{U}$ test. 
Table 2 Prevalence and odds ratio (OR) of airway symptoms according to exposure from oil tank explosion

\begin{tabular}{|c|c|c|c|c|c|c|c|c|}
\hline & \multirow[b]{2}{*}{ Control } & \multicolumn{2}{|c|}{ Main group analysis } & \multicolumn{5}{|c|}{ Sub-group analysis } \\
\hline & & Exposed & $\begin{array}{c}\text { Exposed } \\
(<6 \mathrm{~km}) \\
\text { vs control }\end{array}$ & $\begin{array}{c}\text { Exposed } \\
3-6 \mathrm{~km}\end{array}$ & $\begin{array}{l}\text { Exposed } \\
(3-6 \mathrm{~km}) \\
\text { vs control }\end{array}$ & $\begin{array}{c}\text { Exposed } \\
<3 \mathrm{~km}\end{array}$ & $\begin{array}{l}\text { Exposed } \\
(<3 \mathrm{~km}) \\
\text { vs control }\end{array}$ & $\begin{array}{c}\text { Linear trend: } \\
\text { control/ } \\
3-6 \mathrm{~km} /<3 \mathrm{~km}\end{array}$ \\
\hline & $n=179$ & $n=223$ & & $n=114$ & & $n=109$ & & \\
\hline & n (\%) & n (\%) & OR $(95 \% C l)^{\mathrm{ab}}$ & $\%$ & OR $(95 \% C l)^{a b}$ & $\%$ & OR $(95 \% \mathrm{Cl})^{\mathrm{ab}}$ & P-value ${ }^{b}$ \\
\hline Blocked nose & $37(21)$ & $71(32)$ & $1.7(1.0,2.8)$ & 28 & $1.5(0.8,2.6)$ & 36 & $2.0(1.1,3.6)$ & 0.020 \\
\hline Rhinorrhoea & $24(13)$ & $52(23)$ & $1.9(1.1,3.4)$ & 21 & $1.6(0.9,3.1)$ & 26 & $2.4(1.2,4.6)$ & 0.010 \\
\hline Irritated nose & $24(13)$ & $79(35)$ & $3.4(2.0,5.9)$ & 34 & $3.2(1.7,5.9)$ & 37 & $3.7(2.0,7.0)$ & $<0.001$ \\
\hline Sore throat & $22(12)$ & $73(33)$ & $3.1(1.8,5.5)$ & 34 & $3.4(1.8,6.3)$ & 31 & $2.9(1.5,6.6)$ & 0.001 \\
\hline Morning cough & $26(15)$ & $74(33)$ & $3.5(2.0,6.2)$ & 33 & $3.0(1.6,5.7)$ & 33 & $4.3(2.2,6.7)$ & $<0.001$ \\
\hline Daily cough & $42(24)$ & $91(42)$ & $2.3(1.4,3.7)$ & 38 & $1.8(1.0,3.1)$ & 46 & $3.0(1.7,6.4)$ & $<0.001$ \\
\hline Cough $>3 \mathrm{mo} / \mathrm{yr}$ & $21(12)$ & $64(29)$ & $2.9(1.5,5.3)$ & 24 & $2.1(1.0,4.3)$ & 34 & $4.1(2.0,8.4)$ & $<0.001$ \\
\hline Cough with phlegm & $45(26)$ & $82(38)$ & $1.9(1.2,3.1)$ & 39 & $1.8(1.0,3.2$ & 37 & $2.1(1.2,3.8)$ & 0.010 \\
\hline Cough with phlegm $>3 \mathrm{mo} / \mathrm{yr}$ & $11(6)$ & $39(17)$ & $2.9(1.3,6.2)$ & 13 & $1.6(0.6,3.8)$ & 22 & $5.7(2.3,14.2)$ & $<0.001$ \\
\hline Dyspnoeic walking flat & $13(7)$ & $30(14)$ & $1.8(0.9,3.8)$ & 15 & $1.8(0.8,4.0)$ & 12 & $1.9(0.8,4.5)$ & 0.132 \\
\hline Dyspnoeic walking uphill & $44(25)$ & $75(35)$ & $1.5(0.9,2.4)$ & 33 & $1.3(0.7,2.3)$ & 37 & $1.7(0.95,3.0)$ & 0.075 \\
\hline Ever chest wheeze & $21(12)$ & $36(16)$ & $1.7(0.8,3.2)$ & 15 & $1.3(0.6,2.9)$ & 17 & $2.2(0.98,4.9)$ & 0.061 \\
\hline
\end{tabular}

Exposed status was defined as living $<6 \mathrm{~km}$ (average $3.7 \mathrm{~km}$ ) from the explosion site; control status as living $>20 \mathrm{~km}$ (average $28 \mathrm{~km}$ ) from the explosion site. Increasing intensity of exposure within the exposed group was defined by dividing the exposed group in those living 3-6 km (average $4.7 \mathrm{~km}$ ) and $<3 \mathrm{~km}$ (average $2.6 \mathrm{~km}$ ) from the explosion site.

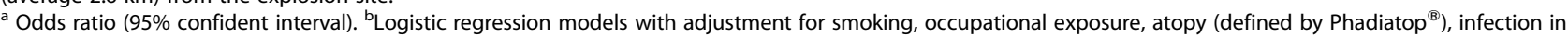
the preceding month, post-traumatic stress impact score, age and gender.

Smoking, Phadiatop ${ }^{\circledR}$ and impact score also had odds ratios above two, but among men estimates were higher for home address close to the accident site (Table 4).

Linear multiple regression analyses with men and women together and controlling for covariates, showed lower lung function in the exposed group living $<6 \mathrm{~km}$ from the accident site than in the control group living $>20 \mathrm{~km}$ away, significant for $\mathrm{FEV}_{1}(\mathrm{~mL})$, FVC (mL) and FVC\% predicted (Table 5). In linear multiple regression analyses lower $\mathrm{FEV}_{1}(\mathrm{~mL})$ and FVC (mL) were also found among both men and women in the exposed group $(<6 \mathrm{~km})$ when controlling for covariates, but the findings were only statistically significant for FVC among men (Table 6). Among men, these lung function values were lower in the within-three-kilometre group than the three-tosix-kilometre group (Table 6).

In a logistic regression model adjusting for covariates there were more obstructive lung functions, defined as $\mathrm{FEV}_{1} \%$ predicted below $80 \%$ and an $\mathrm{FEV}_{1} / \mathrm{FVC}$ ratio below 0.70 , in the exposed group for men and women together, and were significant for pre-bronchodilator measurements and nearly significant $(p=0.054)$ for post-bronchodilator measurements compared to the control group (Table 5). The prevalence of obstructive lung function was also higher in the exposed group for men and women separately (Table 6), and the figures became significant when analysing the genders together. The association of exposure with more symptoms and lower lung function was apparently similar among atopic and non-atopic (defined by Phadiatop ${ }^{\circledR}$ ) in stratified analyses (Additional file 1.Table 1 in on-line repository and Table 2 in on-line repository).

\section{Discussion}

One and a half years after an explosion and fire in two tanks in a small industrial harbour, the individuals living within six kilometres of the explosion site had a doubled risk of airway symptoms as compared to a control group living more than twenty kilometres away. This was found for both upper and lower airway symptoms. An exposure-response relationship was significant with more symptoms among individuals living within three kilometres from the explosion site as compared to those living slightly further away, and this trend was also significant for men separately. The exposed individuals also had lower lung function and more airway obstruction (GOLD II/III) compared with the control group. Furthermore lung function was lower both among exposed men and women separately and became significant when analysing the genders together.

The findings of more airway symptoms in the exposed group are in accordance with a study conducted eight to 16 months after the WTC incident, where residents living within one and a half kilometres from ground zero had more coughs, wheezes and dyspnoea [3], and more nose irritation and sore throats [4], than a control group of residents living 
Table 3 Prevalence and odds ratio (OR) of airway symptoms according to exposure from oil tank explosion in men and women

\begin{tabular}{|c|c|c|c|c|c|c|c|c|}
\hline & & Main $\mathbf{g}$ & oup analysis & & & ub-group & nalysis & \\
\hline & Control & Exposed & $\begin{array}{c}\text { Exposed } \\
(<6 \mathrm{~km}) \\
\text { vs control } \\
\end{array}$ & $\begin{array}{l}\text { Exposed } \\
3-6 \mathrm{~km}\end{array}$ & $\begin{array}{c}\text { Exposed } \\
(3-6 \mathrm{~km}) \\
\text { vs control } \\
\end{array}$ & $\begin{array}{c}\text { Exposed } \\
<3 \mathrm{~km}\end{array}$ & $\begin{array}{c}\text { Exposed } \\
(<3 \mathrm{~km}) \\
\text { vs control } \\
\end{array}$ & $\begin{array}{c}\text { Linear trend: } \\
\text { control/ } \\
3-6 \mathrm{~km} /<3 \mathrm{~km}\end{array}$ \\
\hline Men & $n=99$ & $n=115$ & & $\mathrm{n}=59$ & & $n=56$ & & \\
\hline & n (\%) & n (\%) & OR $(95 \% C l)^{\mathrm{ab}}$ & $\%$ & $\mathrm{OR}(95 \% \mathrm{Cl})^{\mathrm{ab}}$ & $\%$ & OR $(95 \% \mathrm{Cl})^{\mathrm{ab}}$ & P-value ${ }^{b}$ \\
\hline Blocked nose & $24(24)$ & $41(36)$ & $1.8(0.9,3.5)$ & 32 & $1.5(0.7,3.3)$ & 39 & $2.2(1.0,5.0)$ & 0.046 \\
\hline Rhinorrhoea & $13(13)$ & $29(25)$ & $1.9(0.8,4.8)$ & 24 & $2.2(0.9,5.3)$ & 27 & $2.8(1.1,7.3)$ & 0.03 \\
\hline Irritated nose & $15(15)$ & $45(39)$ & $3.1(1.4,7.2)$ & 36 & $3.4(1.5,7.8)$ & 43 & $4.9(2.0,12)$ & $<0.001$ \\
\hline Sore throat & $15(15)$ & $37(32)$ & $2.5(1.2,5.2)$ & 37 & $3.0(1.3,6.8)$ & 27 & $1.8(0.7,4.7)$ & 0.10 \\
\hline Morning cough & $21(21)$ & $37(32)$ & $2.1(1.0,4.4)$ & 29 & $1.4(0.6,3.3)$ & 36 & $3.7(1.5,9.1)$ & 0.007 \\
\hline Daily cough & $30(30)$ & $52(45)$ & $2.0(1.1,3.7)$ & 36 & $1.2(0.6,2.5)$ & 56 & $3.7(1.7,8.2)$ & 0.002 \\
\hline Cough $>3 \mathrm{mo} / \mathrm{yr}$ & $16(16)$ & $36(31)$ & $2.5(1.2,5.3)$ & 24 & $1.5(0.6,3.7)$ & 39 & $4.6(1.8,11)$ & 0.008 \\
\hline Cough with phlegm & $31(32)$ & $50(44)$ & $1.9(1.0,3.6)$ & 45 & $1.6(0.7,3.3)$ & 45 & $2.4(1.1,5.2)$ & 0.03 \\
\hline Cough with phlegm $>3 \mathrm{mo} / \mathrm{yr}$ & $9(9)$ & $25(22)$ & $2.7(1.1,6.6)$ & 14 & $1.2(0.4,3.6)$ & 30 & $6.7(2.3,20)$ & 0.003 \\
\hline Dyspnoeic walking flat & $9(9)$ & $13(12)$ & $1.1(0.4,3.0)$ & 16 & $1.4(0.5,4.1)$ & 7 & $0.7(0.2,3.0)$ & 0.81 \\
\hline Dyspnoeic walking uphill & $20(21)$ & $38(33)$ & $1.8(0.9,3.7)$ & 36 & $1.7(0.7,3.7)$ & 33 & $2.1(0.9,5.0)$ & 0.08 \\
\hline Ever chest wheeze & $13(13)$ & $19(17)$ & $1.7(0.7,4.5)$ & 18 & $1.5(0.5,4.5)$ & 16 & $2.1(0.6,6.7)$ & 0.23 \\
\hline Women & $\mathrm{n}=80$ & $n=108$ & & $n=55$ & & $n=53$ & & \\
\hline Blocked nose & $13(16)$ & $30(28)$ & $1.6(0.7,3.4)$ & 24 & $1.4(0.6,3.6)$ & 32 & $1.7(0.7,4.2)$ & 0.25 \\
\hline Rhinorrhoea & $11(14)$ & $23(22)$ & $1.5(0.7,3.5)$ & 18 & $1.2(0.4,3.1)$ & 25 & $2.0(0.8,5.2)$ & 0.17 \\
\hline Irritated nose & $9(11)$ & $34(32)$ & $2.9(1.2,6.7)$ & 33 & $3.0(1.1,7.6)$ & 30 & $2.8(1.0,7.5)$ & 0.04 \\
\hline Sore throat & $7(9)$ & $36(33)$ & $4.1(1.6,10)$ & 31 & $3.7(1.3,10)$ & 36 & $4.7(1.6,13.7)$ & 0.003 \\
\hline Morning cough & $5(6)$ & $37(34)$ & - & 38 & - & 30 & - & - \\
\hline Daily cough & $12(15)$ & $39(36)$ & $2.5(1.1,5.5)$ & 39 & $2.6(1.1,6.5)$ & 36 & $2.4(0.95,6.0)$ & 0.054 \\
\hline Cough $>3 \mathrm{mo} / \mathrm{yr}$ & $5(6)$ & $28(26)$ & - & 24 & - & 28 & - & - \\
\hline Cough with phlegm & $14(19)$ & $32(30)$ & $2.0(0.9,4.6)$ & 33 & $2.0(0.8,4.8)$ & 28 & $2.2(0.8,4.9)$ & 0.09 \\
\hline Cough with phlegm $>3 \mathrm{mo} / \mathrm{yr}$ & $2(3)$ & $14(13)$ & - & 13 & - & 13 & - & - \\
\hline Dyspnoeic walking flat & $4(5)$ & $17(16)$ & - & 15 & - & 17 & - & - \\
\hline Dyspnoeic walking uphill & $24(30)$ & $37(34)$ & $1.0(0.5,2.0)$ & 29 & $0.8(0.4,1.9)$ & 42 & $1.3(0.6,2.8)$ & 0.63 \\
\hline Ever chest wheeze & $8(10)$ & $17(16)$ & $1.4(0.5,3.8)$ & 13 & $1.0(0.3,3.4)$ & 19 & $1.9(0.6,6.0)$ & 0.29 \\
\hline
\end{tabular}

more than nine kilometres away. Similarly, there was a strong association between exposure to combustion products within 100 metres of the Drachten fire and persistent coughing, wheezing and dyspnoea six years later [5]. This study differed from ours in terms of the distance from the pollution site and time since exposure. In a questionnaire-based interview study carried out one to two weeks after the oil spill caused by the tanker Braer running aground in Shetland, people living within four and a half kilometres from the wreck reported more sore throats, itchy eyes, skin irritation and headaches than a control population living 95 kilometres away [24]. Symptoms diminished significantly in the exposed group over time, but throat irritation and breathlessness on exertion were still higher than in the control group after six months [25].

In our study, there were significantly more airway symptoms in the exposure group, also when adjusting for the PTSD-related impact scores. Individuals living within four and a half kilometres from the wreck of the Braer had more depressive and PTSD-related symptoms than the control group six months after the accident [25]. Three months after the WTC disaster, workers employed by a company near ground zero reported more symptoms, including coughing, wheezing, eye irritation and nose/throat irritation, but also more depressive and PTSD symptoms than office workers in the same company in Dallas [2]. In analyses of the Prestige 
Table 4 Logistic regression models for daily cough among men and women after the oil tank explosion

\begin{tabular}{|c|c|c|c|}
\hline & & \multicolumn{2}{|c|}{ Daily cough } \\
\hline & & Men & Women \\
\hline & & OR $(95 \% \mathrm{CI})^{\mathrm{a}}$ & OR $(95 \% \mathrm{Cl})^{\mathrm{a}}$ \\
\hline \multirow[t]{3}{*}{ Distance between home address and explosion site } & $>20 \mathrm{~km}$ & 1.0 & 1.0 \\
\hline & $3-6 \mathrm{~km}$ & $1.2(0.6,2.5)$ & $2.6(1.1,6.5)$ \\
\hline & $<3 \mathrm{~km}$ & $3.7(1.7,8.2)$ & $2.4(1.0,6.0)$ \\
\hline Smoking & Present vs ex/never & $2.9(1.4,5.7)$ & $3.5(1.5,8.0)$ \\
\hline Occupational exposure & High vs low & $1.2(0.6,2.3)$ & $1.3(0.4,4.8)$ \\
\hline Atopy & Phadiatop $\left.^{(}\right)$pos vs neg & $2.3(1.1,5.0)$ & $2.6(1.1,3.6)$ \\
\hline Infection in the preceding month & Yes vs no & $1.8(0.9,3.4)$ & $1.7(0.8,3.6)$ \\
\hline Impact score & $\geq 22$ vs $<22$ & $3.5(0.8,6.1)$ & $2.1(0.5,8.9)$ \\
\hline Age & Continuous & $1.03(1.00,1.05)$ & $1.00(0.98,1.03)$ \\
\hline
\end{tabular}

a Odds ratio (95\% confidence interval).

oil spill study, a significantly higher risk of lower respiratory tract symptoms was found among fishermen who took part in clean-up activities, after adjustments were made for reported anxiety and participants believing that the exposure had affected their health [6]. The same adjustments were made in the survey of residents seven weeks after the grounding of the oil tanker Sea Empress, where residents showed more symptoms, including runny noses, sore throats and coughs than a control group [26].

The exposed participants in our study had significantly lower lung function and more spirometric airway obstruction. This has not been found or analysed in previous studies of lung function after similar accidents. When comparing exposed and control groups, lung function was not significantly different in connection with the Drachten fire [5], among residents living around ground zero, NY [3], and in the Prestige oil spill studies [7].
As this was a cross-sectional study and the population was not examined before the explosion, it is difficult to know whether the higher frequency of airway symptoms, lower lung function and signs of airway obstruction in the exposed group were caused by pollution from the oil tank explosion or by other factors. The contamination from the explosion consisted of different hydrocarbon compounds mixed with sulphur products, and the pollution in the area lasted for two years. However, information about concentration levels of air pollutants in the area was scarce, and the exposure level was probably low. Previous studies have shown bronchial effects of sulphur dioxide $[27,28]$, and people exposed to malodorous sulphuric air pollution including hydrogen sulphide and mercaptans as a result of living near pulp mills reported more coughing, pharyngeal irritation, breathing problems and eye symptoms than control groups living in a non-polluted community [29]. Thus, it seems plausible that the findings could be related to air pollution.

Table 5 Lung function measures according to exposure from oil tank explosion

\begin{tabular}{|c|c|c|c|}
\hline & \multirow{2}{*}{$\begin{array}{l}\text { Control } \\
n=162\end{array}$} & \multirow{2}{*}{$\begin{array}{c}\text { Exposed } \\
n=193\end{array}$} & \multirow[t]{2}{*}{ Difference between exposed and control } \\
\hline & & & \\
\hline & $\mathrm{AM}(\mathrm{SD})^{a}$ & $\mathrm{AM}(\mathrm{SD})^{\mathrm{a}}$ & AM difference ${ }^{a}(95 \% \mathrm{Cl})^{b}$ \\
\hline $\mathrm{FEV}_{1}(\mathrm{~mL})$ & $3437(860)$ & $3273(915)$ & $-123(-232,-14)$ \\
\hline FEV $\%$ predicted & $92.9(13.6)$ & $89.5(15.1)$ & $-2.5(-5.5,0.5)$ \\
\hline FVC (mL) & $4486(1046)$ & $4248(1076)$ & $-173(-297,-50)$ \\
\hline FVC \% predicted & $99.7(11.9)$ & $96.3(13.4)$ & $-3.1(-5.9,-0.4)$ \\
\hline \multirow[t]{2}{*}{$\mathrm{FEV}_{1} / \mathrm{FVC}$ ratio } & $0.767(0.072)$ & $0.766(0.083)$ & $-0.001(0.014,0.013)$ \\
\hline & $\mathrm{n}(\%)$ & $\mathrm{n}(\%)$ & Odds ratio $(95 \% \mathrm{Cl})^{\mathrm{d}}$ \\
\hline Airway obstruction` before salbutamol & $8(5)$ & $21(11)$ & $2.5(1.0,6.2)$ \\
\hline Airway obstruction` ${ }^{c}$ after salbutamol & $5(3)$ & $15(8)$ & $3.1(0.98,9.6)$ \\
\hline \multicolumn{4}{|c|}{ 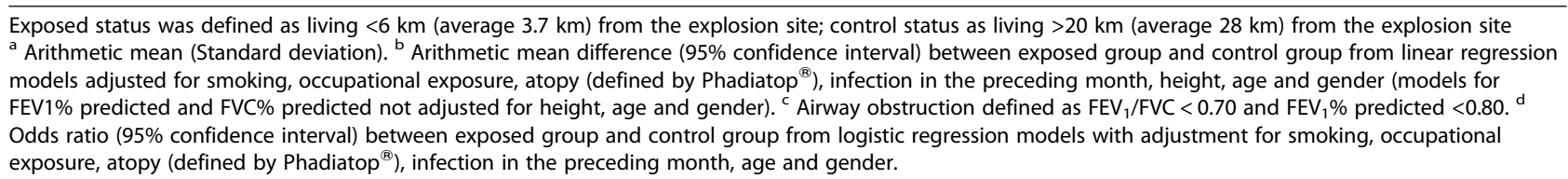 } \\
\hline
\end{tabular}


Table 6 Lung function measures according to exposure from oil tank explosion in men and women

\begin{tabular}{|c|c|c|c|c|c|}
\hline & Control & Exposed & $\begin{array}{l}\text { Difference between } \\
\text { exposed }<6 \mathrm{~km} \\
\text { and control }\end{array}$ & $\begin{array}{l}\text { Difference between } \\
\text { exposed 3-6km } \\
\text { and control }\end{array}$ & $\begin{array}{c}\text { Difference between } \\
\text { exposed }<3 \mathrm{~km} \\
\text { and control }\end{array}$ \\
\hline \multirow[t]{2}{*}{ Men } & $n=91$ & $n=99$ & & & \\
\hline & $\mathrm{AM}(\mathrm{SD})^{\mathrm{a}}$ & $\mathrm{AM}(\mathrm{SD})^{\mathrm{a}}$ & AM difference $(95 \% \mathrm{Cl})^{\mathrm{b}}$ & AM difference $(95 \% \mathrm{Cl})^{\mathrm{b}}$ & AM difference $(95 \% \mathrm{Cl})^{\mathrm{b}}$ \\
\hline$\overline{F E V_{1}(m L)}$ & $3860(827)$ & $3746(843)$ & $-137(-307,32)$ & $-87(-336,161)$ & $-194(-406,18)$ \\
\hline FEV $\%$ predicted & $90.7(13.8)$ & $88.5(14.9)$ & $-1.6(-5.7,2.5)$ & $-0.6(-6.6,5.4)$ & $-2.7(-8.8,3.5)$ \\
\hline$\overline{F V C}(\mathrm{~mL})$ & $5125(843)$ & $4902(880)$ & $-242(-435,-50)$ & $-212(-497,73)$ & $-275(-569,18)$ \\
\hline FVC\% predicted & $99.5(11.8)$ & $96.1(13.0)$ & $-3.7(-7.4,0.0)$ & $-2.4(-7.9,3)$ & $-5.1(-10.6,0.5)$ \\
\hline \multirow[t]{2}{*}{$\mathrm{FEV}_{1} / \mathrm{FVC}$ ratio } & $0.75(0,08)$ & $0.76(0,08)$ & $0.01(-0.01,0.03)$ & $0.02(-0.01,0.05)$ & $0.00(-0.02,0.03)$ \\
\hline & n (\%) & n (\%) & & & \\
\hline Airway obstruction ${ }^{c}$ before salbutamol & $5(6)$ & $14(14)$ & & & \\
\hline Airway obstruction ${ }^{\mathrm{C}}$ after salbutamol & $4(4)$ & $9(9)$ & & & \\
\hline \multirow[t]{2}{*}{ Women } & $n=71$ & $n=94$ & & & \\
\hline & $\mathrm{AM}(\mathrm{SD})^{\mathrm{a}}$ & $\mathrm{AM}(\mathrm{SD})^{\mathrm{a}}$ & AM difference $(95 \% \mathrm{Cl})^{\mathrm{b}}$ & AM difference $(95 \% \mathrm{Cl})^{\mathrm{b}}$ & AM difference $(95 \% \mathrm{Cl})^{\mathrm{b}}$ \\
\hline $\mathrm{FEV}_{1}(\mathrm{~mL})$ & $2896(543)$ & $2775(700)$ & $-99(-235,37)$ & $-206(-402,-10)$ & $5(-190,199)$ \\
\hline FEV $\%$ predicted & $95.7(12.8)$ & $90.6(15,4)$ & $-3.5(-8.1,1.1)$ & $-7.2(-13.9,-0.5)$ & $0.0(-6.6,6.5)$ \\
\hline $\mathrm{FVC}(\mathrm{mL})$ & $3667(625)$ & $3567(807)$ & $-92(-250,87)$ & $-252(-478,-27)$ & $66(-158,289)$ \\
\hline FVC\% predicted & $99.8(12,2)$ & $96.6(13.8))$ & $-1.6(-6.4,3.2)$ & $-6.5(-12.6,-0.4)$ & $1.0(-5.0,7.0)$ \\
\hline \multirow[t]{2}{*}{$\mathrm{FEV}_{1} / \mathrm{FVC}$ ratio } & $0.80(0.06)$ & $0.77(0.09)$ & $-0.01(-0.3,0.01)$ & $-0.01(-4.2,2.3)$ & $-1.4(-4.6,1.9)$ \\
\hline & n (\%) & n (\%) & & & \\
\hline Airway obstructionc before salbutamol & $3(4)$ & $7(7)$ & & & \\
\hline Airway obstructionc after salbutamol & $1(2)$ & $6(6)$ & & & \\
\hline
\end{tabular}

However, there may have been air pollution from other sources before the event, such as from the ordinary industrial activity in the industrial harbour. This cannot be assessed in the present study, as we have no information about the health of the population before the explosion. This study took part in two rural municipalities with no other industrial emission sites than the industrial harbour, with generally low road traffic and without town or city in the neighbourhood.

Strengths of our study are that both exposed and control individuals were recruited from the same municipalities, and that the groups were comparable except for their relationship to the accident site. The variables indicating socioeconomic and demographic conditions confirmed that the groups were highly comparable. The few factors that were different were adjusted for in the analyses. We used present smoking as a factor for the effect of smoking on the airways. Pack years might have been a better measure, but we did not have this information. However, years of smoking and present cigarettes smoked per day among smokers were not significantly different between the groups.

The low response rate in the control group may have resulted in selection bias, but we do not know whether this could have influenced the two groups differentially. The majority of the non-responders were younger people, especially younger men. In the examined municipalities, some individuals stay away from their homes for days at a time because of working or studying elsewhere. They could have been among the healthier nonresponders and thus have contributed to lower odds ratio in the study than expected in the total population. Some anticipate more health problem among nonresponders [30]. If so, we would have expected lower odds ratios than registered in this study.

\section{Conclusions}

Individuals who lived near the industrial harbour where two tanks with a heterogeneous mixture of sulphuric hydrocarbons exploded and caught fire in May 2007 had more upper and lower airway symptoms, lower lung function and more airway obstruction than a comparable control group one and a half years after the accident. Both pollution from the accident and the industrial activities in the industrial harbour may have contributed. A follow-up study of the population in question will be performed to investigate long-term consequences of the accident. The findings add to reports on how industrial 
accidents may have health consequences for the general population living near an industrial plant in an otherwise rural area. Industrial planning must include the health concern of the general population also in case of accidents.

\section{Additional file}

Additional file 1: Airway symptoms and lung function measures according to oil tank explosion among Phadiatop ${ }^{\circledR}$ positive and negative for exposed related to controls. Table 1 in on-line repository. Prevalence of airway symptoms among exposed and control subjects $\geq 18$ years old stratified on Phadiatop ${ }^{\circledR}$ negative and positive, and odds ratios for exposed with controls as reference. Table 2 in on-line repository. Spirometry results among exposed and control subjects $\geq 18$ years old stratified on atopy status; Phadiatop ${ }^{\circledR}$ negative and positive, and adjusted mean difference between exposed and controls.

\section{Abbreviations}

FVC: Forced vital capacity; FEV 1 \% \%redicted Forced expiratory volume in one second; IES-R: Impact of Event Scale- Revised; GOLD: The Global Initiative for Chronic Obstructive Lung Disease.

\section{Competing interests}

All authors declared that they have no competing interest.

\section{Authors' contributions}

JTG contributed in designing and data collection, undertook the analyses, drafted and revised the manuscript after consultation with the other authors. $\mathrm{MB}, \mathrm{BEM}, \mathrm{A} \mathrm{l}, \mathrm{BEH} ; \mathrm{NM}$ contributed to the study design and revised and approved the manuscript. BEH and NM took part in data collection and Ål in statistical analyses. CS revised and approved the manuscript. All authors read and approved the final manuscript.

\section{Acknowledgments}

The authors are grateful to Berit Johannessen, Arnt Troland, Anne Kari Mjanger, the MDs Svein Gunnar Sivertsen and Eivind A.S. Steinsvik, the administration and local physicians of Gulen and Masfjorden municipalities, the administration and staff of the laboratory of Haukeland University hospital, and the people who participated in this study

\section{Funding}

The study was funded by the Ministry of Health and Care Services, Norway and Haukeland University Hospital, Bergen

\section{Author details}

'Department of Occupational Medicine, Haukeland University Hospital, Bergen, Norway. ${ }^{2}$ Department of Public Health and Primary Health Care, University of Bergen, Bergen, Norway. ${ }^{3}$ Institute of Medicine, University of Bergen, Bergen, Norway.

Received: 13 January 2012 Accepted: 5 December 2012 Published: 12 December 2012

\section{References}

1. Tande RM, Norman T, Asheim TK, Midtbø M, Berg AL: Rapport om helseplagar i Gulen og Masfjorden kommunar etter ulukka i Vest Tank sitt anlegg i Sløvåg 24.05.2007; 2008. (Report in Norwegian); 2008. Available at http://www.helse- bergen.no/fagfolk/temasider/sloevaagundersokinga/ Documents/rapportar/Gulen\%20og\%20Masjorden\% 20kommunehelserapport.pdf Last accessed 11-12-2012.

2. Trout D, Nimgade A, Mueller C, Hall R, Earnest GS: Health effects and occupational exposures among office workers near the world trade center disaster site. J Occup Environ Med 2002, 44:601-605.

3. Reibman J, Lin S, Hwang SA, Gulati M, Bowers JA, Rogers I, Berger KI Hoerning A, Gormez M, Fitzgerald EF: The world trade center residents' respiratory health study; new- onset respiratory symptoms and pulmonary function. Environ Health Perspect 2005, 113:406-411.
4. Lin S, Reibman J, Bowers JA, Hwang S-A, Hoerning A, Gomez MI, Fitzgerald EF: Upper respiratory symptoms and other health effects among residents living near the world trade center site after September 11, 2001. Am J Epidemiol 2005, 162:499-507.

5. Greven F, Kerstjens HAM, Duijm F, Eppinga P, de Meer G, Heederik D: Respiratory effects in the aftermath of a major fire in a chemical waste depot. Scand J Work Environ Health 2009, 35:368-375.

6. Zock JP, Rodriguez-Trigo G, Pozo-Rodrigues F, Barberà JA, Bousso L, Torralba Y, Antó JM, Gómez FP, Fuster C, Verea H: Prolonged respiratory symptoms in clean-up workers of the prestige oil spill. Am J Respir Crit Care Med 2007, 176:610-616.

7. Rodríguez-Trigo G, Zock JP, Pozo-Rodrigues F, Gómez FP, Monyarch G, Bouso L, Coll MD, Verea H, Antó JM, Fuster C, Barberà JA: I. Health changes in fishermen 2 years after the clean-up of the prestige oil spill. Ann Intern Med 2010, 153:489-498.

8. Vasterman P, Yzermans CJ, Dirkzwager AJE: The role of the media and media hypes in the aftermath of disasters. Epidemiol Rev 2005, 27:107-114

9. Eid J, Larsson G, Johnsen BH, Laberg JC, Bartone BT, Carlstedt B: Psychometric properties of the Norwegian impact of event scale- revised in a non-clinical sample. Nord J Psychiatr 2009, 63:426-432.

10. Rasmussen S: Luftprøver for analyse av svovelholdige forbindelser og løsemidler-Vest Tank. Bergen, Norway: Rapport X-lab; 2007. Report in Norwegian.

11. American Thoracic Society-Division of Lung Diseases: Recommended respiratory disease questionnaires for use with adults and children in epidemiological research (ATS-DLD-78-A). American Thoracic Society.; 1978. http://www.thoracic.org/statements/index.php Last accessed 11-12-2012.

12. Wasserfallen JB, Gold K, Schulman KA, Baraniuk JN: Development and validation of a rhinoconjunctivitis and asthma symptom score for use as an outcome measure in clinical trials. J Allergy Clin Immunol 1997, 100:16-22.

13. Miller MR, Hankinson J, Brusasco F, Burgos F, Casaburi R, Coates A, Crapo R, Enright P, van der Grinten CP, Gustafsson P, Jensen R, Johnson DC, Maclntyre N, Mckay R, Navajas D, Pedersen OF, Pellegrino R, Viegi G, Wanger J: Standardisation of spirometry. Series "ATS/ERS task force: standardisation of lung function testing. Eur Respir J 2005, 26:319-338.

14. American Thoracic Society: Standardization of spirometry, 1994 update. Am J Resp Crit Care Med 1995, 152:1107-1136.

15. Gulsvik A, Tosteson T, Bakke P, Humerfelt S, Weiss ST, Speizer FE: Expiratory and inspiratory forced vital capacity and one-second forced volume in asymptomatic never- smokers in Norway. Clin Physiol 2001, 6:648-660.

16. Pellegrino R, Viegi G, Brusasco V, Crapo RO, Burgos F, Casaburi R, et al: Interpretive strategies for lung function tests. Eur Respir J 2005, 26:948-968

17. Rabe KF, Hurd S, Anzueto A, Barnes PJ, Buist SA, Calverley P, et al: Global strategy for the diagnosis, management and prevention of chronic obstructive pulmonary disease. Am J Respir Crit Care Med 2007, 176:532-555.

18. Weiss DS, Marmar CR: The impact of event scale- revised. In Assessing psychological trauma and PTDS: a handbook for reactioners. Edited by Wilson JP, Keane TM. New York: Guilford Press; 1997:399-411.

19. Creamer M, Bell R, Failla S: Psychometric properties of the impact of event scale-revised. Behav Res Ther 2003, 41:1489-1496.

20. Rash CJ, Coffey SF, Baschnagel JS, Drobes DJ, Saladin ME: Psychometric properties of the IES-R in traumatized substance dependent individuals with and without PTSD. Addict Behav 2008, 33:1039-1047.

21. Statistics Norway: Standard classification of occupations. Oslo-Kongsvinger: Official Statistics of Norway; 1999.

22. Skorge TD, Eagan TML, Eide GE, Gulsvik A, Bakke PS: Occupational exposure and incidence of respiratory disorders in a general population. Scand I Work Environ Health 2009, 35:454-460.

23. DeCoster J, Iselin A-M R, Gallucci M: A conceptual and empirical examination of justifications for dichotomization. Psychol Meth 2009, 14:349-366.

24. Campbell D, Cox D, Crum J, Foster K, Christie P, Brewster D: Initial effects of the grounding of the tanker braer on health in Shetland. BMJ 1993, 307:1251-1255.

25. Campbell D, Cox D, Crum J, Foster K, Riley A: Later effects of grounding of tanker braer on health in Shetland. BMJ 1994, 309:773-774. 
26. Lyons RA, Temple JMF, Evans D, Fone DL, Palmer SR: Acute health effects of the Sea empress oil spill. J Epidemiol Community Health 1999, 53:306-310.

27. Bernstein JA, Alexis N, Barnes C, Bernstein JA, Nel A, Peden D, Diaz-Sanchez D, Tarlo SM, Williams PB: Health effects of air pollution. J Allergy Clin Immunol 2004, 114:1116-1123.

28. Forbes LJ, Kapetanakis V, Rudnicka AR, Cook DG, Bush T, Stedman JR, Whincup PH, Strachan DP, Anderson HR: Chronic exposure to outdoor air pollution and lung function in adults. Thorax 2009, 64:657-663.

29. Jaakkola JJK, Partti-Pellinen K, Marttila O, Miettinen P, Vilkka V, Haahtela T: The south Karelia Air pollution study: changes in respiratory health in relation to emission reduction of malodorous sulfur compounds from pulp mills. Arch Environ Health 1999, 54:254-263.

30. Rönmark $E$, Lundqvist $A$, Lundbäck $B$, Nyström L: Non-responders to a postal questionnaire on respiratory symptoms and diseases. Eur J Epidemiol 1999, 15:293-299.

doi:10.1186/1471-2466-12-76

Cite this article as: Granslo et al:: Airway symptoms and lung function in the local population after the oil tank explosion in Gulen, Norway. BMC Pulmonary Medicine 2012 12:76.

\section{Submit your next manuscript to BioMed Central and take full advantage of:}

- Convenient online submission

- Thorough peer review

- No space constraints or color figure charges

- Immediate publication on acceptance

- Inclusion in PubMed, CAS, Scopus and Google Scholar

- Research which is freely available for redistribution 